\title{
A Survey of Campus Coordinators of Undergraduate Research Programs
}

\author{
Merinda Kaye Hensley, Sarah L. Shreeves, and \\ Stephanie Davis-Kahl
}

\begin{abstract}
Interest in supporting undergraduate research programs continues to grow within academic librarianship. This article presents how undergraduate research program coordinators perceive and value library support of their programs. Undergraduate research coordinators from a variety of institutions were surveyed on which elements of libraries and library services they valued, and where libraries could improve and develop services for undergraduate researchers and their faculty mentors. This article seeks to present a critical perspective on library support for undergraduate research programs from an important external constituent group of faculty and administrators. The data and recommendations can further conversations and aid collaboration between librarians and their campus colleagues.
\end{abstract}

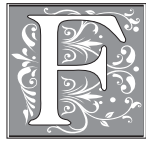

ormal undergraduate research programs are flourishing across the academy. "Reinventing Undergraduate Education: A Blueprint for America's Research Universities," most frequently referred to as the Boyer Report, outlined ten specific recommendations for research universities to address "a new model of undergraduate education at research universities that makes the baccalaureate experience an inseparable part of an integrated whole." ${ }^{11}$ Developing programs to support undergraduate research, defined as "an inquiry or investigation conducted by an undergraduate student that makes an original intellectual or creative contribution to the discipline," is one of the recommendations. ${ }^{2}$ The Boyer Report continues to be heavily referenced in the literature and has influenced curricular changes in higher education toward a more concrete focus on practices that enrich and increase undergraduate engagement. The Association of American Colleges and Universities (AAC\&U) designated undergraduate research as a high-impact practice in 2008. ${ }^{3}$ In fact, there has been a consistent growth in undergraduate research programs across all types of institutions and disciplines, as evidenced by the expansion of the Council on Undergraduate Research (CUR), which represents the interests of faculty members, campus coordinators, provosts and deans, and students in advocacy for and development of undergraduate research programs. In the past decade, the CUR has added the Health Science Division and the Arts \& Humanities Division and has

Merinda Kaye Hensley is Assistant Professor and Instructional Services Librarian and Scholarly Commons Co-Coordinator in the University Library at the University of Illinois at Urbana-Champaign, e-mail:mhensle1@ illinois.edu; Sarah L. Shreeves is Associate Dean for Digital Strategies at the University of Miami, e-mail: sshreeves@miami.edu; Stephanie Davis-Kahl is Professor and Scholarly Communications Librarian at Illinois Wesleyan University, e-mail: sdaviska@iwu.edu. (C2015 Merinda Kaye Hensley, Sarah L. Shreeves, and Stephanie Davis-Kahl, Attribution-NonCommercial (http://creativecommons.org/licenses/by-nc/3.0/) CC BY-NC. 
expanded its membership to include community colleges, historically black colleges, and institutions outside North America.

Concurrently, interest in supporting undergraduate research continues to grow within academic librarianship. Since the researchers began research in this area in 2011, the Association of College and Research Libraries (ACRL) has taken steps to recognize the need for libraries to provide services and research support specifically designed for undergraduate researchers. An ACRL white paper titled "The Intersections of Information Literacy and Scholarly Communication" was released in 2013 and outlined a broad conceptual framework for how libraries could align information literacy activities to increase efforts for student learning in areas of scholarly communication. It included several examples of libraries working with undergraduate researchers. ${ }^{4}$ Additionally, the recent completion of the "ACRL Framework for Information Literacy for Higher Education" includes "students as creators" as one of the guiding elements of the document and expands the role of library instruction to include the dissemination and preservation of original student work..$^{5}$ Furthermore, a number of publications over the past two years have demonstrated how libraries are actively seeking opportunities to support students and faculty mentors involved in undergraduate research. ${ }^{6}$ The 2012 Ithaka S+R US Faculty Survey offers an avenue for collaboration with faculty, stating "about $45 \%$ of respondents agreed that librarians help students to 'develop their research skills,' with a slight majority agreeing that libraries 'contribute significantly to my students' learning by helping them to find, access, and make use of a range of secondary and primary sources in their coursework."'7 However, the survey also noted that fewer respondents from the sciences agreed with both statements, which may represent a challenge for those librarians wishing to work with our faculty colleagues in these disciplines.

The authors of this article previously published a benchmark survey of library support for formal undergraduate research programs. ${ }^{8}$ The researchers observed that libraries are supporting undergraduate research programs in a variety of ways including: offering collaboration and study space, information literacy instruction, collection support, assistance with designing and printing research posters, publishing support, dissemination and preservation of undergraduate work, and hosting and planning student symposia and conferences. The data also showed that there is considerable interest in further engagement on this topic; 66 percent of respondents indicated that a future forum to discuss and share information around issues related to undergraduate research would be helpful.

While individual libraries may assess the effectiveness and the value of their programs, there has not been an attempt to capture the perceptions of a principal stakeholder group - administrators of undergraduate research programs (URPs) - of library support for URPs. This article seeks to further the conversation by asking how URP administrators perceive and value library support of their programs. The researchers sought to understand what elements of a library and its services administrators find valuable and what services librarians could improve to meet the needs of undergraduate researchers and their faculty mentors. This research fills a gap in the library and higher education literature and seeks to represent a critical perspective on library support for undergraduate research programs. Librarians can use the data and recommendations to further conversations with their campus colleagues. It is important that librarians and URP administrators come together to discuss best practices for supporting student researchers and faculty mentors, and it is the researchers' hope that this article aids in catalyzing new and improved services and relationships.

\section{Literature Review}

The literature on undergraduate research within librarianship is nascent. Within the higher education literature, as well as other disciplines, there is very little discussion of 
library support for URPs. There has been almost no attention paid toward stakeholder perceptions of library support for such programs in any literature.

The Council on Undergraduate Research (CUR) promotes conversation related to undergraduate research by sponsoring a biennial conference and disseminating publications examining a wide variety of issues, usually of interest to faculty mentors and URP coordinators. A recently published volume of essays, "Characteristics of Excellence in Undergraduate Research," is a "summary of best practices that support and sustain highly effective undergraduate research environments" but there are few mentions of library support. ${ }^{9}$ Several chapter authors recognize library acquisitions as an essential element in administering effective campuswide undergraduate research efforts; one noted that, "Inadequate library resources can be a significant barrier to the productivity and long-term success of an undergraduate research program." ${ }^{10}$ While this statement suggests the high value that faculty place on collections support for their own research and for their students, there is no mention of information literacy or other collaborative efforts with librarians. The library is mentioned with other campuswide services such as the "computer center, student health and counseling centers, recreation center, food services, etc." ${ }^{11}$ In another recently published CUR volume, "Creative Inquiry in the Arts \& Humanities," Klos shares a case study of a research methods course in the humanities that is cotaught by a faculty member and a librarian in which the students are required to produce an annotated bibliography. ${ }^{12}$ Shanahan shares a rubric of the scaffolding process for learning how to perform effective research in the humanities and encourages students writing a senior thesis to consult with the research librarian assigned to the course..$^{13}$ While such references may implicitly indicate that library support is valued, they are few and far between, which may indicate that teaching faculty do not have a full understanding for the scope of efforts, particularly educational efforts, made by librarians in supporting undergraduate research, that librarians have not done a sufficient job in marketing their services, and/or that the services and support provided were not worth mentioning (for whatever reason).

\section{Methodology}

The goal of the survey was to understand how administrators of undergraduate research programs understood and perceived the contributions of their libraries to such programs. The researchers were interested in how administrators valued these contributions and what other services or support they thought libraries could provide. The survey was meant to be a complement to the previous survey of library support of undergraduate research programs.

\section{Survey Design}

The instrument was a branched survey consisting of 15 total questions (see appendix A for the instrument and accompanying e-mail). Only one question was required (Q1). The questions were a mixture of types, including multiple-choice, open-ended, and a Likert-scale question.

The survey was divided into three sections:

1. Description of the undergraduate research program and services (Questions 1-4)

2. Identification of how libraries are involved (or not) in undergraduate research programs and the value of such participation (Questions 5-11)

3. Demographic and contact information (Questions 12-15)

In the introduction of the survey, undergraduate research programs were defined using the commonly cited CUR definition. The survey was heavily influenced by the responses to the previous survey, which provides a benchmark of library support for 
undergraduate research programs; in particular, the researchers were able to broaden and refine answer choices based on experience with the previous survey.

Description of the Undergraduate Research Program and Services (Q1-4): In this section, the researchers wanted to determine first that the respondent did, in fact, administer an undergraduate research program. Then, because such programs can be administered in a variety of ways, Q1 was structured to allow a broader range of respondents including administrators of a college or departmental level and faculty mentors. Respondents who answered "I don't know" or "no" to this question were directed to the last section of the survey to provide demographic information. Respondents who answered that they had some role in an undergraduate research program or who answered "other" were asked to provide which disciplines the program served (Q2-3) and the type of activities and services were offered through the program (Q4).

Identification of how libraries are involved (or not) in undergraduate research programs and the value of such participation (Q5-11): In this section, the most extensive, the respondents were asked a number of questions about library support for undergraduate research programs. The researchers first wanted to establish whether the library provided support (Q5), and, if not, why not (Q6). If a respondent answered "no" to Q5, he or she was directed to Q6 and then directed to the last question in this section, which asked what the library could do to provide such support (Q11).

If respondents answered "yes," "under development, " or "other" to Q5, they were directed to two questions that were meant to assess a respondent's perception of the value of library support for undergraduate research programs. Respondents were asked in Q7 whether or not they agreed with the statement, "The library is important to the success of the undergraduate research program." A 5-point Likert scale was used to assess agreement or disagreement with that statement. In Q8, the survey's most complicated question, respondents were asked to assess the value of individual components of library support or to indicate either that their library did not provide the service or that they did not know whether their library provided the service. It is important to note that respondents were not asked to rank these components or to assess their value in relation to each other. Q9 asked how librarians were involved in the program, and Q10 asked what other resources the library was providing for the program. Q11 was an open-ended question inquiring, "What services could your library provide that could strengthen the undergraduate research program and student work?" Note that all respondents who answered in the affirmative or "other" to Q1 had an opportunity to respond to Q11.

Demographic and Contact Information (Q12-15): The final set of questions asked for basic information about the institution of the respondent, including its name and the size of the undergraduate student body. The survey also asked for the title of the respondent, and an e-mail address if the respondent was willing to be contacted for follow-up questions.

The survey was developed with input from colleagues with survey construction expertise. The survey instrument and protocols were reviewed by the Institutional Review Board at both the University of Illinois at Urbana-Champaign and Illinois Wesleyan University but were found to be exempt, given that the study was focused on services offered by institutions. The survey was piloted with three respondents representing a large public research university and a small private liberal arts college, and revisions were made accordingly before sending out the survey for wider distribution.

\section{Survey Population and Dissemination}

The survey was sent to administrators of undergraduate research programs using the same set of institutions that were developed in the 2012 research on library support for 
undergraduate research programs ${ }^{14}$ The researchers were interested in comparing the responses of the two surveys in which institutions were identified. The original survey (developed in 2012) used the membership of CUR ( $n=627$ in 2012, $n=697$ in 2014), the Association of Research Libraries (ARL) ( $n=125$ in 2012 and 2014), the Oberlin Group ( $\mathrm{n}=80$ in 2012 and 2014), and the National Institute for Technology in Liberal Education (NITLE) ( $\mathrm{n}=139$ in 2012, n=93 in 2014). Where an institution belonged to one or more of these organizations, the institution was only included once. The membership lists were not rechecked in 2014, hence the analysis includes some institutions that are no longer members of any of these organizations.

The Carnegie Basic and Control Classifications was used to characterize the survey population. Approximately half of the institutions surveyed were private, not-forprofit $(n=377 ; 50 \%)$; the remainder were public $(n=381 ; 50 \%)$. There were no private, for-profit institutions in the survey population. Twenty-seven percent $(n=205)$ were doctorate-granting institutions, 39 percent $(n=299)$ were masters colleges or universities, 28 percent $(n=210)$ were baccalaureate colleges, and the remainder $(5.9 \%)$ were associate, special focus, or tribal institutions. The majority of institutions were based in the United States. It should be noted that this population is not representative of the total population of institutions of higher education within the United States (as counted by the Carnegie Foundation for the Advancement of Teaching). For example, the percentage of doctorate-granting research universities in the survey population is much higher than that of the total population $(27 \%$ of the survey population versus $6 \%$ of the total population) and that of associate, special focus, or tribal institutions is very low (5.9\% of the survey population versus $34.9 \%$ of the total population). ${ }^{15}$

Campuses generally fall into one of two categories when it comes to organizing undergraduate research efforts: either there is a centralized office supporting undergraduate research or efforts are distributed across a campus with administrators seated in colleges or departments. For each institution, the lead administrator or coordinator of the undergraduate research program was identified through a review of institutional web pages as well as through a database maintained by the Council on Undergraduate Research. In cases where there was not a campuswide program, a program or a contact at a more granular level was identified (at the college level, for example) using the CUR database; in some cases, these contacts were simply faculty mentors for undergraduate researchers. A contact was identified at all institutions within the survey population. A survey invitation was sent to each of these individuals $(n=758)$ with a link to the survey (which was available through Survey Monkey). In a handful of cases, a notice was received that the person was no longer at the institution; in those cases, the researchers were able to identify another contact to whom to send the survey. The survey also stated that it could be forwarded to a more appropriate individual. The survey was open July 15 through August 13, 2013. At two points during this period, follow-up e-mails were sent to those who had not responded to the survey as well as those who had responded but did not leave a name or institution (as we were unable to remove their names from the distribution list).

\section{Survey Results}

\section{Response Rate and Characterization of the Demographic of Respondents}

After reviewing and cleaning the data, there were a total of 304 respondents out of 758 , for a 40 percent response rate. Further review of the data identified that 6 percent $(n=17)$ of the respondents could be characterized as junk responses (duplicates, for example) and discarded. This left a total of 287 respondents or approximately a 38 percent response rate. These 287 respondents represented 246 institutions; 32 (11\%) did not provide an institution name, and there were multiple respondents ( 9 total) from 
6 institutions. Of these 246 institutions, 84 percent $(n=207)$ were members of CUR, 12 percent $(n=29)$ were members of NITLE, 13 percent $(n=36)$ were members of the Oberlin Group, and 17 percent $(n=42)$ were members of ARL. Twenty-five percent $(n=61)$ were members of two or more of these organizations. This represents a response rate of 30 percent of the CUR membership, 31 percent of the NITLE membership, 45 percent of the Oberlin Group membership, and 34 percent of the ARL membership. Sixteen (6.5\%) institutions were not a member of any of these organizations; the researchers assume that these institutions dropped their membership in one or more of these organizations since the original survey population was developed in 2012 . Thirty percent $(n=87 / 287)$ had replied to the 2012 survey benchmarking library support for URPs; 70 percent $(n=200)$ had not or we could not determine whether they had.

Using the Carnegie Basic and Control Classifications, the 237 respondents were characterized which provided institutional information and were based in the United States. ${ }^{16}$ Four percent $(n=10)$ were classified as associate-level institutions, 29 percent $(n=68)$ were classified as baccalaureate-level institutions, 35 percent $(n=82)$ were categorized as masters-level institutions, and 31 percent $(n=74)$ were classified as research institutions. Three institutions (1\%) were classified as special-focus institutions, 45 percent $(n=106)$ were private, not-for-profit institutions, and 55 percent $(n=131)$ were public institutions. The highest number of respondents $(n=58 ; 25 \%)$ were private, baccalaureate colleges. (See table 1 for a further breakdown of the respondents.)

\begin{tabular}{|l|c|c|c|}
\hline \multicolumn{4}{|c|}{$\begin{array}{c}\text { TABLE 1 } \\
\text { Respondents (Providing Institutional Information) Categorized } \\
\text { According to Carnegie Basic and Control Classifications (n=237) } \\
\text { (Bold=Highest percentage in each category) }\end{array}$} \\
\hline Carnegie Basic Classification & Private & Public & Total \\
\hline Associate's Colleges & 0 & $10(4 \%)$ & $10(4 \%)$ \\
\hline Baccalaureate Colleges & $\mathbf{5 8 ~ ( 2 5 \% )}$ & $10(4 \%)$ & $68(29 \%)$ \\
\hline Master's Colleges and Universities & $31(13 \%)$ & $51(22 \%)$ & $\mathbf{8 2}(\mathbf{3 5 \%})$ \\
\hline Doctorate-Granting Universities & $17(7 \%)$ & $\mathbf{5 7 ( 2 4 \% )}$ & $74(31 \%)$ \\
\hline Special Focus & 0 & $3(1 \%)$ & $3(1 \%)$ \\
\hline Total (n=237) & $106(45 \%)$ & $\mathbf{1 3 1}(\mathbf{5 5 \%})$ & $237(100 \%)$ \\
\hline
\end{tabular}

\section{Institutional Support for Undergraduate Research}

Of the 287 analyzed responses, 59 percent $(n=166)$ responded that they were responsible for the undergraduate research program at a campus level. Twenty-two percent $(n=63)$ responded that they were responsible for the undergraduate research program at a college or department level, and 11 percent $(n=33)$ responded that they were faculty mentors in undergraduate research programs. Five percent $(n=15)$ selected other," and only 3 percent $(n=10)$ responded that they did not have roles in undergraduate research programs. Those who answered "no" were sent to the end of the survey (Q12) to provide demographic information; they did not see Q2-11.

As discovered in previous research, undergraduate research programs appear to be active across disciplines. Respondents who answered that they were responsible for the undergraduate research programs at a campus level or "other" were asked to indicate in which disciplinary areas their institutions have undergraduate research programs in Q2 ( $\mathrm{n}=181 ; 100 \%)$. Those who responded that they were responsible at college or department levels or that they were faculty mentors were directed to a similar question in Q3 
( $n=96 ; 100 \%$ ). Unsurprisingly, the majority of respondents who were responsible for URPs across campus stated that their programs were active across all disciplines; however, the majority of respondents who were responsible at college or department levels represented programs in Life Sciences and Physical Sciences, with less representation from the Social Sciences and Humanities. Table 2 gives a breakdown of the disciplinary areas represented.

\begin{tabular}{|l|c|c|c|}
\hline \multicolumn{5}{|c|}{$\begin{array}{c}\text { TABLE 2 } \\
\text { Disciplinary Areas with Undergraduate Research Programs (n=277) } \\
\text { (Bold=Highest percentage in each category; Note that more than one } \\
\text { discipline could be selected; totals do not equal 100\%) }\end{array}$} \\
\hline Disciplinary Area & $\begin{array}{c}\text { Campus Level } \\
\text { (n=181) }\end{array}$ & $\begin{array}{c}\text { College/Dept/ } \\
\text { Faculty (n=96) }\end{array}$ & $\begin{array}{c}\text { Total } \\
(\mathbf{n = 2 7 7 )}\end{array}$ \\
\hline Business & $60(33 \%)$ & $3(3 \%)$ & $63(23 \%)$ \\
\hline Education & $55(30 \%)$ & $10(10 \%)$ & $65(23 \%)$ \\
\hline Fine Arts & $69(38 \%)$ & $9(9 \%)$ & $78(28 \%)$ \\
\hline Humanities & $87(48 \%)$ & $18(19 \%)$ & $105(38 \%)$ \\
\hline Life Sciences & $94(52 \%)$ & $\mathbf{4 5}(\mathbf{4 7 \%})$ & $\mathbf{1 3 9}(\mathbf{5 0 \% )}$ \\
\hline Physical Sciences & $95(52 \%)$ & $37(40 \%)$ & $132(48 \%)$ \\
\hline PreMed/Nursing & $48(27 \%)$ & $17(19 \%)$ & $65(23 \%)$ \\
\hline Social Sciences & $92(51 \%)$ & $20(21 \%)$ & $112(40 \%)$ \\
\hline Interdisciplinary & $61(34 \%)$ & $20(21 \%)$ & $81(29 \%)$ \\
\hline All Disciplinary Areas & $\mathbf{1 0 6}(\mathbf{5 9 \% )}$ & - & $106(38 \%)$ \\
\hline Other & $9(5 \%)$ & $14(15 \%)$ & $23(8 \%)$ \\
\hline
\end{tabular}

In Q4 ( $\mathrm{n}=277 ; 100 \%)$, the survey asked what type of services and programs were offered or sponsored as part of the undergraduate research program. The most commonly offered services or programs were: travel funds $(n=254 ; 97 \%)$, research symposia $(n=252 ; 91 \%)$, formal faculty mentoring $(n=224 ; 81 \%)$, and summer research opportunities $(n=211 ; 76 \%)$. (A breakdown of the services and programs offered by respondent type can be seen in table 3.) Services often supported by libraries-workshops, journals, and archiving student work online-are not yet as common.

\section{Library Support for Undergraduate Research Programs and Perceptions Thereof}

Q5 ( $\mathrm{n}=274 ; 99 \%)$ asked respondents whether the library provided support specific to the undergraduate research program. Fifty-four percent $(n=149)$ responded that it did or that the support was under development. Eight percent $(n=23)$ answered that they did not know, and 3 percent $(n=9)$ answered "other." Thirty-four percent $(n=93)$ responded that the library did not provide support for undergraduate research programs. These were sent to Q6 (n=93; 100\%), which asked them to specify why the library did not provide services. The researchers note that the responses are reliant on the respondents' perceptions and understandings, which could be faulty (and in fact, in a small number of cases, is, as highlighted in the discussion). As found in the previous research, the most common reason specified was that the library offered the same services to all undergraduates $(n=68 ; 73 \%)$. The second most common reason (and perhaps the most disheartening) was that they had never thought of it ( $\mathrm{n}=25 ; 27 \%)$.

Those who answered "yes," "under development," and "other" were sent to Q7 $(\mathrm{n}=158 ; 100 \%)$, which asked the respondents to specify whether they agreed or dis- 


\begin{tabular}{|l|c|c|c|}
\hline \multicolumn{4}{|c|}{ TABLE 3 } \\
\begin{tabular}{|l|c|} 
Services and Programs Offered by Campus or College/Department (n=277) \\
(Bold=Highest percentage in each category; Note that more than one service/ \\
program could be selected; totals do not equal 100\%)
\end{tabular} \\
\hline Service or Program & $\begin{array}{c}\text { Respondent } \\
\text { Responsible } \\
\text { at Campus } \\
\text { Level (n=181) }\end{array}$ & $\begin{array}{c}\text { Respondent } \\
\text { Responsible at } \\
\text { College/Dept/ } \\
\text { Faculty (n=96) }\end{array}$ & $\begin{array}{c}\text { Total } \\
(\mathbf{n}=\mathbf{2 7 7})\end{array}$ \\
\hline Undergraduate Journal & $79(44 \%)$ & $32(33 \%)$ & $111(40 \%)$ \\
\hline Research Symposium & $\mathbf{1 6 8 ( 9 3 \% )}$ & $84(88 \%)$ & $252(91 \%)$ \\
\hline Formal Faculty Mentoring & $147(81 \%)$ & $77(80 \%)$ & $224(81 \%)$ \\
\hline Summer Research Opportunities & $149(82 \%)$ & $62(65 \%)$ & $211(76 \%)$ \\
\hline Travel Funds & $165(91 \%)$ & $\mathbf{8 5}(\mathbf{8 9} \%)$ & $\mathbf{2 5 4}(\mathbf{9 7 \%})$ \\
\hline Student Work Available Online & $88(49 \%)$ & $41(43 \%)$ & $129(47 \%)$ \\
\hline Workshops & $122(67 \%)$ & $39(41 \%)$ & $161(58 \%)$ \\
\hline Awards for Best Student Work & $100(55 \%)$ & $43(45 \%)$ & $143(52 \%)$ \\
\hline Dedicated Space & $36(20 \%)$ & $39(41 \%)$ & $75(27 \%)$ \\
\hline I Don't Know & $2(1 \%)$ & 0 & $2(1 \%)$ \\
\hline Other & $13(7 \%)$ & $4(4 \%)$ & $17(6 \%)$ \\
\hline
\end{tabular}

agreed (via a Likert scale) with the statement, "The library is important to the success of the undergraduate program." Eighty-seven percent $(n=138)$ of respondents agreed or strongly agreed with the statement. Six percent $(n=9)$ neither agreed nor disagreed, and 7 percent $(n=11)$ strongly disagreed with the statement. No one selected the gradient of "disagree." Of the eleven who responded with "strongly disagree," the data was examined for possible explanations within the open-ended Q11, which asked for suggestions for library services that could strengthen undergraduate research. Six respondents shared some insight: provide a general introduction to the library for all undergraduate research students; more research-focused instruction followed by individual work with research groups; poster printing; support for an online database of student work; and, interestingly, one compliment recognizing the success of a current partnership. The researchers were also interested in understanding whether these percentages changed if the question was broken down by respondent type (that is to say, responsible at campus level, responsible at college or department level, or faculty mentor). In most cases, the responses were roughly similar, except that all of those who strongly disagreed with the statement were responsible for undergraduate research programs at the campus level. (See table 4 for a breakdown of how different respondent types replied to Q7.)

In Q8, respondents were asked to rank library services in terms of their value for support of student work and their campus undergraduate research program. This was the most complicated question; because the researchers were interested in only assessing the value of services offered, the survey also asked respondents to indicate if the service was not offered or if they did not know whether the service was offered. Table 5 provides a breakdown of the responses. Easily the most valued element of library programs was instruction on research and publication, with 87 percent $(n=111)$ ranking it as "More Valuable." Expanded support for collections was ranked the second most valuable service, with 73 percent $(n=71)$ of respondents ranking it "More Valuable." 


\begin{tabular}{|c|c|c|c|c|c|c|}
\hline $\begin{array}{r}\text { Agreement with } \\
\text { Undergraduate Res }\end{array}$ & $\begin{array}{r}\text { tatemen } \\
\text { rch Pro } \\
\text { pe }\end{array}$ & $\begin{array}{l}\text { TA } \\
\text { "6he Li } \\
\text { am" by } \\
\text { entage i }\end{array}$ & $\begin{array}{l}\text { LE } 4 \\
\text { rary is Impo } \\
\text { ype of Resp } \\
\text { each catego }\end{array}$ & $\begin{array}{l}\text { net to } \\
\text { ent (n }\end{array}$ & $\begin{array}{l}\text { Succes } \\
\text { 58) (Bo }\end{array}$ & $\begin{array}{l}\text { the } \\
\text { Highest }\end{array}$ \\
\hline Respondent Type & $\begin{array}{c}\text { Strongly } \\
\text { Disagree } \\
\text { (1) }\end{array}$ & $\begin{array}{l}\text { Disagree } \\
\text { (2) }\end{array}$ & $\begin{array}{c}\text { Neither Agree } \\
\text { nor Disagree } \\
\text { (3) }\end{array}$ & $\begin{array}{l}\text { Agree } \\
\text { (4) }\end{array}$ & $\begin{array}{l}\text { Strongly } \\
\text { Agree } \\
\text { (5) }\end{array}$ & Average \\
\hline $\begin{array}{l}\text { Responsible at Campus } \\
\text { Level }(\mathrm{n}=123)\end{array}$ & $11(9 \%)$ & 0 & $7(6 \%)$ & $43(35 \%)$ & $62(50 \%)$ & 4.18 \\
\hline $\begin{array}{l}\text { Responsible at College/ } \\
\text { Dept Level }(n=24)\end{array}$ & 0 & 0 & $1(4 \%)$ & $11(46 \%)$ & $12(50 \%)$ & 4.46 \\
\hline Faculty Mentor $(\mathrm{n}=11)$ & 0 & 0 & $1(9 \%)$ & $5(45 \%)$ & $5(45 \%)$ & 4.36 \\
\hline Total $(n=158)$ & $11(7 \%)$ & 0 & $9(6 \%)$ & $59(37 \%)$ & $79(50 \%)$ & 4.23 \\
\hline
\end{tabular}

The least offered service was Awards (for best papers or posters), with 61 percent $(n=95)$ of respondents indicating that the library did not offer that service. Respondents who added their own examples referenced collaborations with the campus writing center, library building expansions to include space for undergraduate researchers, and librarians as resources for students in undergraduate research programs. Two respondents reported that, in some cases, the undergraduate research center, not the library, provided the services listed in Q8.

Q9 ( $=154 ; 98 \%)$ and Q10 ( $=154 ; 98 \%)$ asked in what other ways the respondents understood how the library contributed to the undergraduate research program. Q9 focused on what roles librarians played, if any, in the structure of the undergraduate research program. Eighteen percent $(n=28)$ responded that librarians are not involved in the undergraduate research program, while 44 percent $(n=67)$ reported that a librarian (or more than one) was assigned as a liaison. In the previous survey, 59.9 percent $(n=100)$ of respondents reported that no single librarian had been assigned to provide support to campus undergraduate research programs. ${ }^{17} \mathrm{Q} 10$ asked whether the library provided funding beyond human resources to support services. Forty percent $(n=61)$ responded that the library did not provide any other funding. Twenty-nine percent $(n=45)$ noted that the library provided collections. In analyzing the open-ended responses from Q11 in relation to this question, three respondents did suggest that the library could underwrite speakers and help to pay for the cost of a student symposium.

Q11 ( $\mathrm{n}=157 ; 57 \%)$, was an open-ended question asking, "What services could your library provide that could strengthen the undergraduate research program and student work?" All respondents to Q5 onward (n=274) had an opportunity to answer this question. The responses were multifaceted and reaffirmed numerous services already mentioned in the survey and uncovered suggestions for areas of growth. Thirty-four percent $(n=53)$ of the responses to Q11 mentioned instruction, workshops, short courses, specialized training, tutorials or research seminars, with one respondent noting, "We are in the process of developing a series of seminars on topics related to student research. The library is a full partner in this process, making the program more accessible to students across campus. They also promote undergraduate research within their space, and of course work one-on-one with students seeking research support." Suggested topics for instruction were varied and included general research skills (such as how to find materials in the library, using research tools, how to search for articles, literature reviews), with 40 percent of those suggestions specific either to special formats, such as archival materials or scientific literature, or to the skills needed to effectively share 


\begin{tabular}{|c|c|c|c|c|c|c|c|}
\hline \multicolumn{8}{|c|}{$a z$} \\
\hline $\begin{array}{l}\text { Service Type (number of } \\
\text { respondents/ response rate) }\end{array}$ & $\begin{array}{l}\text { Service } \\
\text { Offered (n / } \\
\% \text { of total) }\end{array}$ & $\begin{array}{l}\text { More Valuable }=3 \\
\text { (n / \% of those } \\
\text { who offer service) }\end{array}$ & $\begin{array}{l}\text { Neutral=2 (n / } \\
\% \text { of those who } \\
\text { offer service) }\end{array}$ & $\begin{array}{l}\text { Less Valuable }=1 \\
\text { (n / \% of those } \\
\text { who offer service) }\end{array}$ & Average & $\begin{array}{l}\text { I don't know } \\
\text { if offered (n / } \\
\% \text { of total) }\end{array}$ & $\begin{array}{l}\text { Not offered } \\
\text { (n/\% of } \\
\text { total) }\end{array}$ \\
\hline Space $(n=152 / 96 \%)$ & $108(71 \%)$ & $56(52 \%)$ & $40(37 \%)$ & $12(11 \%)$ & 2.4 & $16(11 \%)$ & $28(18 \%)$ \\
\hline $\begin{array}{l}\text { Instruction on research and } \\
\text { publication } \\
(\mathrm{n}=152 / 96 \%)\end{array}$ & $128(84 \%)$ & $111(87 \%)$ & $16(13 \%)$ & $1(1 \%)$ & 2.9 & $13(9 \%)$ & $11(7 \%)$ \\
\hline $\begin{array}{l}\text { Expanded support for collections } \\
(\mathrm{n}=154 / 97 \%)\end{array}$ & $97(63 \%)$ & $71(73 \%)$ & $20(21 \%)$ & $6(6 \%)$ & 2.7 & $31(20 \%)$ & $26(17 \%)$ \\
\hline $\begin{array}{l}\text { Design and/or printing of research } \\
\text { posters and publications }(\mathrm{n}=155 / \\
98 \%)\end{array}$ & $64(41 \%)$ & $46(72 \%)$ & $12(19 \%)$ & $6(9 \%)$ & 2.6 & $13(8 \%)$ & $78(50 \%)$ \\
\hline $\begin{array}{l}\text { Hosting undergraduate research } \\
\text { journals }(\mathrm{n}=153 / 97 \%)\end{array}$ & $52(34 \%)$ & $34(65 \%)$ & $13(25 \%)$ & $5(10 \%)$ & 2.6 & $20(13 \%)$ & $81(53 \%)$ \\
\hline $\begin{array}{l}\text { Making available online original } \\
\text { student research, including creative } \\
\text { works }(\mathrm{n}=154 / 97 \%)\end{array}$ & $77(50 \%)$ & $58(75 \%)$ & $16(21 \%)$ & $3(4 \%)$ & 2.7 & $18(12 \%)$ & $58(38 \%)$ \\
\hline $\begin{array}{l}\text { Awards (e.g. for best papers or } \\
\text { posters) }(155 / 98 \%)\end{array}$ & $51(33 \%)$ & $28(55 \%)$ & $16(31 \%)$ & $7(14 \%)$ & 2.4 & $9(6 \%)$ & $95(61 \%)$ \\
\hline $\begin{array}{l}\text { Assistance with securing rights for } \\
\text { material included in publications } \\
(\mathrm{n}=154 / 97 \%)\end{array}$ & $80(52 \%)$ & $50(63 \%)$ & $26(33 \%)$ & $4(5 \%)$ & 2.6 & $47(30 \%)$ & $27(18 \%)$ \\
\hline $\begin{array}{l}\text { Hosting or collaborating with other } \\
\text { units to sponsor research symposia } \\
(\mathrm{n}=152 / 96 \%)\end{array}$ & $77(51 \%)$ & $52(68 \%)$ & $22(29 \%)$ & $3(4 \%)$ & 2.6 & $11(7 \%)$ & $64(42 \%)$ \\
\hline
\end{tabular}


products of research and creative activity. These included: practicing for presentations or speeches, designing posters, creating PowerPoint slides, or simply writing and presenting. This most common response for more information literacy instruction was not unanticipated given the momentum that academic libraries have seen generally in this area in the past decade.

In terms of dissemination of research, Q11 elicited several mentions of undergraduate research journals and publishing services, as well as archiving and creating public access to products of undergraduate research $(n=30 ; 19 \%)$. One respondent suggested, "The library could take an even more active role in archiving undergraduate research, and in providing support in publishing/disseminating undergraduate research." Another stated, "I like the idea of providing public access to undergraduate work, and I would like to collaborate with them on it."

Other comments referred to more traditional library services. Not surprisingly, a fair number of responses called for access to more research materials, specifying online journals and databases, but also for primary source and archival materials ( $n=30 ; 19 \%)$, which may be an indicator of how undergraduate research programs are growing in the social sciences and humanities. Faster interlibrary loan service was mentioned several times. Dedicated space was also a common response $(n=30 ; 19 \%)$, with a few mentions of use of space to prepare presentations, to provide for group research, or to meet with faculty mentors. In addition, ten respondents highlighted a desire for library space to showcase student work.

There were a few comments that indicated URP administrators were either only relatively satisfied with their library's current level of support or they were skeptical of the library's role in undergraduate research. One respondent remarked, "The most important aspect of library support that students need to learn is finding and then reading the literature in the specific discipline. That however, is probably done more effectively by the faculty." Another was clearly frustrated by a library policy affecting students, "I think that a (sic) the most important change or service is to set aside [the] rule that restrict (sic) librarians to 10 minutes support for a student." Interlibrary loan continues to be a valuable service for undergraduate researchers; one respondent requested, "Full color PDF access to journal articles, rather than blurry black-andwhite Xeroxes of articles supplied through interlibrary loan requests." And another observed, "I guess I just don't look to the library to provide these services. I think the faculty themselves would provide better, more targeted support."

However, several respondents took the opportunity to compliment their library and librarians as well:

Our library serves our department well, and in doing so, they support our undergraduate research program well. We have excellent online access to scientific databases and scientific journals. We have a dedicated science librarian who can help us fid [sic] content and secure resources when needed. We have a very responsive ILL office. There is dedicated staff and equipment on site to help students prepare presentations. We are a primarily undergraduate institution, and thus these resources serve all students. We have not been wanting.

There were also references to collaboration:

We have just begun to strengthen and expand the collaboration between undergraduate research and the libraries, and there is enormous potential. Librarians are offering more skill building workshops for undergrad researchers; they are providing space for undergrad research advising. One of the things that 
has facilitated this increased collaboration is the library's appointment of an Undergraduate Engagement Librarian. Our libraries are also designing a new "research commons" in one of the libraries and have included undergraduate research in the process.

Another attested:

I think that it is a real strength of our library that they consider ways of partnering with other organizations on campus to provide some of the services you listed rather than looking to do all of the work themselves.

The remainder of the questions were demographic in nature (and are included earlier in the overview). The researchers were gratified to see that nearly half ( $n=140 ; 49 \%)$ of the respondents were willing to be contacted for follow-up interviews.

\section{Discussion}

Overall, the data show that URP administrators value the library and the services provided. Many are aware of the roles that librarians have taken on for their institutions related to supporting undergraduate research. Library instruction is highly valued -in particular, instruction that focuses on those skills specific to supporting in-depth research; the researchers believe this may indicate that administrators recognize the role of librarians in teaching competencies such as improving search strategies, literature reviews and annotation, and preparation of research results. These types of sessions could be used as gateways to introduce more advanced information literacy topics. It would also be useful to further and more intentionally integrate issues of scholarly communication into instruction efforts for undergraduate researchers, which would be mutually beneficial to students, librarians, and faculty mentors. The 2012 survey showed that 86 percent $(n=141)$ of libraries are providing instruction to undergraduate researchers, with respondents indicating thriving information literacy activities around the publication and dissemination of original student work. In this survey, we see increasing interest among URP administrators for libraries to participate more fully in this area, which brings with it educative opportunities on copyright, permissions, author rights, and more. Bringing scholarly communication concepts into the classroom would help to establish the library as a partner in all aspects of the lifecycle of scholarship and research.

Libraries are also increasingly well positioned to provide the intellectual and technical infrastructure support for the dissemination of undergraduate research; and, where these services are offered, they were of high value to the respondents. Services such as support for poster creation and printing, student symposia, promotion and exposure of student work, whether through undergraduate research journals or in the institutional repository, were all designated as valuable by respondents; and we predict the demand for these types of services will only continue to expand.

As surveys often spark ideas, several respondents shared innovative suggestions for consideration: collaborate with faculty in research and scholarship intensive courses, invite librarians to act as peer mentors, share visuals that summarize undergraduate research results, acknowledge "best/award-winning" projects, and use social media to showcase student work. There was also the suggestion for training in the use of survey software, something most librarians might associate with the needs of graduate students and faculty. One respondent recommended earmarking funding for collection development initiated by student request because "... it offers students the ability to take research initiative [sic] in an independent manner (and in consultation then with 
librarians)." The researchers hypothesize from these comments that undergraduate researchers may increasingly have more sophisticated research needs than once understood, and that their needs are beginning to more closely mirror the needs of graduate students and faculty, albeit in a novice manner. As undergraduate research programs continue to advance throughout the disciplines, there may be the need to provide more unconventional research services and technology, for example, in areas such as digital humanities and data management. The results also saw evidence of deeper support for undergraduate research in the previous work, with one library conducting an assessment of advanced research needs of undergraduates, and another establishing a lab and hiring a data librarian specifically to support curricular development in that area. ${ }^{18}$

In retrospect, Q8 could have been approached in a different manner. This was a complicated question in which the survey asked respondents to identify the value of specific library services. In looking at the results, it became apparent that some respondents valued all or most of the services, but there was no way of discerning how URP coordinators would rank these services according to their students' needs. This could be especially important for libraries looking to prioritize services in times of tight budgets and limited dedicated personnel. For example, "Assistance with securing rights for material included in publications" would take expertise in the area of copyright and fair use, whereas "Hosting undergraduate research journal(s)" and "Awards (e.g. for best papers or posters)" would require funds in addition to human resources and/or technical infrastructure. If the question were to be revised, it would ask respondents to weigh the services against one another in terms of their perceived value. The question was also murky since it relied on the knowledge of the respondent, who may or may not be familiar with the extent of library services available or possible upon request; as one respondent noted, "In fact, they may offer such things now and I am just unaware of them."

The researchers did identify an opportunity for URP administrators and librarians to increase and improve their communication. While more than half $(54 \% ; n=149)$ of the respondents stated that their institutional library provides or is planning support for undergraduate research programs, on the flip side of this question are the administrators who stated that their institution's library did not provide support (34\%; $=93)$. While it should be acknowledged that the survey relies upon the administrator's knowledge of his or her library's range of services, we wondered if there might be an alignment between the two surveys in which the same institution provided data ${ }^{19}$ Ninety-three respondents from this survey responded that their library did not provide specific support for undergraduate research. Of these, it was determined that the corresponding library had responded to the 2012 survey in 37 cases. Of those 37 URP administrators, 28 stated that their library didn't provide support for undergraduate research, six said that there were currently plans "under development," and three responded, "I don't know." In looking at the same 37 libraries, six libraries stated that their campus does not have an undergraduate research program or they did not know whether it did (when in fact it did). In ten cases, the URP administrators were correct that the library did not offer services for URPs; it should be noted, however, that six libraries stated that they do not provide support because they have not been asked. Of these six, four of the corresponding URP administrators noted that they thought the libraries did not provide services because they offered the same level of service to all undergraduates, one responded that "campus politics" played a role, and one never thought to work with the library. The remainder of the libraries $(n=21)$ did provide some level of service (about which, again, the URP administrator did not know). The services that were identified included providing dedicated space, funding awards, participation in designing curriculum, serving on advisory boards, assignment of liaisons, specialized 
collection development efforts, printing of posters, hosting student journals, instruction on the publishing process, and advocacy and education on open access publishing. These results do indicate a deficit of communication and awareness by both the library and the URP administrator. Clearly, there is an opportunity for better marketing and outreach on the part of those libraries that do offer services to URPs, perhaps including further conversations between those libraries that do not offer services to URPs and their corresponding administrators.

\section{Conclusion}

The possibilities for future research in this area are abundant. The authors of this article plan to use data from the 2012 article and this one to compare the institutions that responded to both surveys; the researchers are also interested in further analyzing the data to look at differences in responses by discipline. The question of the dissemination of student work through showcase versus publishing of undergraduate research is also of interest; and, with increasing attention being placed on how institutions can demonstrate value, this line of research would be beneficial to admissions, student services, and alumni offices as well as the library.

The question of scaling up library services for undergraduate researchers as opposed to offering the same level of services to all undergraduates continues to be a vital question. As libraries develop outreach and engage faculty and undergraduate research offices, will that community begin to express a need for more specialized services? If so, how can the library respond while still maintaining core services for all?

Finally, discerning the impact of working with undergraduate research programs on individual student learning is the ultimate question, one that is wrapped up in several variables unrelated to the library. However, this article unequivocally establishes the value for library support of undergraduate research, and libraries can use the recommendations to inform and improve their contributions so the question of impact can be answered fully from multiple perspectives.

\section{Acknowledgements}

The authors would like to acknowledge the assistance from Help@Ames students at Illinois Wesleyan University who helped to build a comprehensive list of contact information for more than 700 institutions. We are grateful to Frank Boyd and Karen Schmidt of Illinois Wesleyan University and Paul Diehl of the University of Illinois at Urbana-Champaign, who tested the survey. And, finally, many thanks to Glenda Morgan and Joshua Morrill, who reviewed survey methodology and made suggestions for revisions. 


\section{Appendix A. E-mail Sent to Survey Population and Survey Instrument}

\section{E-mail}

You are invited to participate in a survey regarding library support for formal undergraduate research programs. Your institution was chosen because of your undergraduate research program at either a primarily undergraduate institution or a research institution, and/or your institution is a member of the Council on Undergraduate Research (CUR). Your name was identified through a search of your campus website as someone who represents and/or oversees part, or all, of an undergraduate research program(s) on your campus or you may be a faculty mentor. If you feel that we have contacted the wrong person, please feel free to forward this survey to the correct person at your institution or reply to this e-mail.

The University of Illinois at Urbana-Champaign Library and Illinois Wesleyan University would like to know more about how coordinators of undergraduate research programs and faculty mentors perceive and value library support for formal undergraduate research programs. Your feedback will be compiled to inform discussions between librarians and faculty involved in undergraduate research as well as used for future journal articles and professional, disciplinary conferences.

Please complete a short survey to provide us with more information regarding your perception of library support for formal undergraduate research programs through instruction, collections, space, reference consultations, dissemination, and publication.

The survey will take approximately 5-10 minutes to complete. Direct benefits to participation include the opportunity to anonymously reflect on your library's support for formal undergraduate research programs. You may also choose to forward this to a colleague at your institution who can answer this survey.

To access the survey, simply click on the link below. If you have trouble accessing the survey, please contact Merinda Hensley (mhensle1@illinois.edu) for assistance. Your answers are confidential.

https://www.surveymonkey.com/s/ur_coordinators

Please respond by Monday, August 12, 2013.

Should you have any questions about this survey, please contact investigators Merinda Hensley at mhensle1@illinois.edu, Sarah Shreeves at sshreeve@illinois.edu, or Stephanie Davis-Kahl at sdaviska@iwu.edu.

Thank you for your time and consideration. 


\section{Survey Instrument}

PAGE 1

\section{Perceptions of Library Support for Undergraduate Research Programs}

In this survey, we are interested in collecting information about how library support for formal undergraduate research programs is perceived by those administering or coordinating undergraduate research programs.

This survey has been reviewed and approved by the Institutional Review Board at the University of Illinois at Urbana-Champaign. Information that could identify the responses of a specific institution in our analysis will not be shared, only the aggregated results and anonymized comments will be included in publication or presentation. If you have any questions about your rights as a participant in this study or any concerns or complaints, please contact the University of Illinois Institutional Review Board at 217-333-2670 (collect calls will be accepted if you identify yourself as a research participant) or via e-mail at irb@illinois.edu.

This survey is being conducted by Merinda Kaye Hensley and Sarah Shreeves at the University of Illinois at Urbana-Champaign and Stephanie Davis-Kahl at Illinois Wesleyan University. The full survey contains approximately 13 questions and should take 5-10 minutes to complete. You can skip most questions, and it is anonymous unless you want to provide your contact information for further follow-up. The survey will close on August 12, 2013.

By entering the survey, you are acknowledging your consent to participate. If you would prefer not to participate, please exit your browser.

1. Are you responsible for an undergraduate research program, as defined below, at a campus, college, or departmental level, OR are you a faculty mentor for undergraduate research? If you are both responsible for a program AND are a faculty member, please answer the survey in your role as someone responsible for a program. The Council on Undergraduate Research (CUR) defines undergraduate research as: an inquiry or investigation conducted by an undergraduate student that makes an original intellectual or creative contribution to the discipline (http:// www.cur.org/about.html). An undergraduate research program facilitates, supports, and provides opportunities for such undergraduate research.

- $\quad$ Yes, responsible at a campus level (sent to Question 2)

- Yes, responsible at a college or departmental level (sent to Question 3)

- Faculty mentor for undergraduate research (sent to Question 3)

- No (sent to Question 12)

- I don't know (sent to Question 12)

- $\quad$ Other (please specify) (sent to Question 2)

PAGE 2

2. In what disciplinary areas does your institution have undergraduate research programs? (You may check more than one box.) The Council on Undergraduate Research (CUR) defines undergraduate research as: an inquiry or investigation conducted by an undergraduate student that makes an original intellectual or creative contribution to the discipline (http://www.cur.org/about.html). An undergraduate research program facilitates, supports, and provides opportunities for such undergraduate research. (Sent to Question 4) 
- $\quad$ Business

- Education

- Fine Arts

- Humanities

- $\quad$ Life Sciences (including Health and Agriculture)

- $\quad$ PreMed and/or Nursing

- Physical Sciences (including Engineering, Mathematics, and Computer Science)

- $\quad$ Social Sciences (including Anthropology and Psychology)

- Interdisciplinary program

- All Disciplinary Areas

- I don't know

- $\quad$ Other (please specify)

PAGE 3

3. In what disciplinary area(s) is your college or department? (You may check more than one box) (Sent to Question 4)

- Business

- Education

- Fine Arts

- Humanities

- $\quad$ Life Sciences (including Health and Agriculture)

- $\quad$ PreMed and/or Nursing

- Physical Sciences (including Engineering, Mathematics, and Computer Science)

- $\quad$ Social Sciences (including Anthropology and Psychology)

- Interdisciplinary program

- I don't know

PAGE 4

- $\quad$ Other (please specify)

4. On your campus, does your institution, department, or college sponsor or offer any of the following? (Sent to Question 5)

- Undergraduate journal(s)

- Undergraduate research symposium

- Formal faculty mentoring of undergraduate research

- Summer research opportunities (NSF Research Experiences for Undergraduates, McNair Scholars Program, or other)

- Travel funds for students to attend and present at conferences

- Making publicly available online original student work such as research posters, undergraduate honors theses, and creative works

- Workshops on presenting, writing, poster development, and other skills related to presentation and dissemination of research results

- Awards for best student work

- Dedicated space for undergraduate researchers

- I don't know

- $\quad$ Other (please specify)

PAGE 5

In the next set of questions, we will ask you about your perceptions of your library's support (if any) for the undergraduate research programs at the campus, college or departmental level. Library support for formal undergraduate research programs may take the form of instruction, collections, space, reference consultations, and dissemination and/or publication of research results. 
5. Does the college or university library(s) provide support (such as space, instruction, publishing services, etc) specific to any of the formal undergraduate research programs at your institution (as opposed to general services offered to all undergraduates)?

- $\quad$ Yes (Sent to Question 7)

- No (Sent to Question 6)

- Under development (Sent to Question 7)

- I don't know (Sent to Question 11)

- $\quad$ Other (please specify) (Sent to Question 7)

PAGE 6

6. If no, why not? (Choose as many as are applicable) (Sent to Question 11)

- We have asked for support but library is unresponsive

- Library offers same service to all undergraduates

- Campus politics

- Another unit offers the services the library would offer

- Faculty prefer to find support for undergraduate researchers themselves

- Program is at the beginning stages of development

- Never thought of it

- Unnecessary

- Library hasn't approached us

- They used to but don't anymore

- I don't know

- $\quad$ Other (please specify)

PAGE 7

7. The library is important to the success of the undergraduate research program. (Sent to Question 8)

- Strongly disagree

- Disagree

- Neither agree nor disagree

- Agree

PAGE 8

- Strongly agree

8. Of the services that the library offers, please rank these services in terms of their value for support of student work and your campus undergraduate research program. 1 = less valuable and $3=$ more valuable. Please mark the "Service Not Offered" for any services that are not offered by your library. If you do not know whether the service is offered, please mark "I don't know." (Sent to Question 9)

\begin{tabular}{|l|c|c|c|c|c|}
\hline & $\begin{array}{l}\text { Less } \\
\text { Valuable }\end{array}$ & Neutral & $\begin{array}{l}\text { More } \\
\text { Valuable }\end{array}$ & $\begin{array}{l}\text { I don't } \\
\text { know if this } \\
\text { service is } \\
\text { offered by } \\
\text { the library }\end{array}$ & $\begin{array}{l}\text { Service Not } \\
\text { Offered }\end{array}$ \\
\hline Space & o & o & o & o & 0 \\
\hline $\begin{array}{l}\text { Instruction on } \\
\text { research and } \\
\text { publication }\end{array}$ & 0 & 0 & 0 & 0 & 0 \\
\hline
\end{tabular}




\begin{tabular}{|l|c|c|c|c|c|}
\hline $\begin{array}{l}\text { Expanded support } \\
\text { for collections } \\
\text { such as extended } \\
\text { loan periods and } \\
\text { buying specific } \\
\text { materials on } \\
\text { request) }\end{array}$ & 0 & 0 & 0 & 0 & 0 \\
\hline $\begin{array}{l}\text { Design and/ } \\
\text { or printing of } \\
\text { research posters } \\
\text { and publications }\end{array}$ & 0 & 0 & 0 & 0 & 0 \\
\hline $\begin{array}{l}\text { Hosting } \\
\text { undergraduate } \\
\text { research journal(s) }\end{array}$ & 0 & 0 & 0 & 0 & 0 \\
\hline $\begin{array}{l}\text { Making available } \\
\text { online original } \\
\text { student research, } \\
\text { including creative } \\
\text { works }\end{array}$ & 0 & 0 & 0 & 0 & 0 \\
\hline $\begin{array}{l}\text { Awards (for } \\
\text { example, for best } \\
\text { papers or posters) }\end{array}$ & 0 & 0 & 0 & 0 & 0 \\
\hline $\begin{array}{l}\text { Assistance with } \\
\text { securing rights for } \\
\text { material included } \\
\text { in publications }\end{array}$ & 0 & 0 & 0 & 0 & 0 \\
\hline $\begin{array}{l}\text { Hosting or } \\
\text { collaborating with } \\
\text { other units to } \\
\text { sponsor research } \\
\text { symposia }\end{array}$ & 0 & 0 & 0 & 0 & \\
\hline
\end{tabular}

Other (please specify) (text box)

\section{PAGE 9}

9. Are librarians involved in the structure of your campus' undergraduate research program, and, if so, how?

- Librarian(s) is assigned as a liaison

- Serves on an advisory board or steering committee

- $\quad$ Serves as mentor for undergraduates

- Aids in designing curriculum

- Teaches undergraduate research credit-bearing courses

- Serves on planning committee for undergraduate research symposia

- Serves on campuswide award committees

- No, librarians are not involved

- I don't know

- $\quad$ Other (please specify) 
10. Does the library provide funding (besides human resources) to support any of the following? (Sent to Question 11)

- Awards

- Undergraduate research journal

- Printing posters

- Underwriting speakers or other events

- Undergraduate research symposia

- Provision of collections

- No

- I don't know

PAGE 10

- $\quad$ Other (please specify)

11. What services could your library provide that could strengthen the undergraduate research program and student work? (Sent to Question 12)

\section{PAGE 11}

12. Name of your institution

13. What is your job title?

14. What is the size of the undergraduate population at your institution?

- Fewer than 1,000

- $1,000-2,999$

- $3,000-9,999$

- 10,000 or more

15. Are you willing to be contacted for a follow-up interview? If so, please provide your e-mail address below.

\section{PAGE 12}

Thank you very much for taking this survey. The survey results will aid libraries and librarians by benchmarking the current state of library services to undergraduate research programs, and will inform the next stage of our research: examining best practices and strategies for library support of undergraduate research programs. We hope the survey results will also inform conversations between librarians, faculty, and administrators around support of undergraduate research programs.

Please contact Merinda Kaye Hensley (mhensle1@illinois.edu) at the University of Illinois at Urbana-Champaign with any questions. 


\section{Notes}

1. Boyer Commission on Educating Undergraduates in the Research University, Reinventing Undergraduate Education: A Blueprint for America's Research Universities (Stony Brook, N.Y.: State University of New York-Stony Brook, 1998).

2. Definition of Undergraduate Research: "An inquiry or investigation conducted by an undergraduate student that makes an original intellectual or creative contribution to the discipline." See: www.cur.org/about_cur/ [accessed 24 September 2015].

3. George D. Kuh, High-Impact Educational Practices: What They Are, Who Has Access to Them, and Why They Matter (Washington, D.C.: Association of American Colleges and Universities, 2008), available online at www.aacu.org/leap/hips [accessed 24 September 2015].

4. Association of College and Research Libraries, Intersections of Scholarly Communication and Information Literacy: Creating Strategic Collaborations for a Changing Academic Environment, (2013), available online at http://acrl.ala.org/intersections/ [accessed 7 February 2015].

5. Association of College and Research Libraries, Framework for Information Literacy Higher Education (2015), available online at http://www.ala.org/acrl/standards/ilframework/ [accessed 24 September 2015].

6. For example see: Sharon A. Weiner and Charles Watkinson, "What Do Students Learn from Participation in an Undergraduate Research Journal? Results of an Assessment," Journal of Librarianship and Scholarly Communication 2, no. 2 (2014): eP1125, available online at doi:10.7710/21623309.1125; Char Miller and Char Booth, "Open Access as Undergraduate Pedagogy," Library Journal (March 2014), available online at http://j.libraryjournal.com/2014/03/opinion/backtalk/ open-access-as-undergraduate-pedagogy-backtalk [accessed 7 February 2015]; Merinda Kaye Hensley, Benjamin P. Murphy, and Ellen D. Swain, "Analyzing Archival Intelligence: A Collaboration Between Library Instruction and Archives," Communications in Information Literacy 8, no. 1 (2014): 96-114; Amanda H. Brown, Barbara Losoff, Deborah R. Hollis, "Science Instruction through the Visual Arts in Special Collections," portal: Libraries and the Academy 14, no. 2 (Apr. 2014): 197-216; Jeffrey A. Knapp, Nicholas J. Rowland, Eric P. Charles, "Retaining Students by Embedding Librarians into Undergraduate Research Experiences," Reference Services Review 42, no. 1 (2014): 129-147; Stephanie Davis-Kahl, "Engaging Undergraduates in Scholarly Communication: Outreach, Education, and Advocacy," College and Research Libraries News 73, no. 4 (Apr. 2012): 212-222.

7. Roger C. Schonfeld and Ross Housewright, Ithaka S+R US Faculty Survey 2012 (2013), available online at http://sr.ithaka.org/research-publications/us-faculty-survey-2012 [accessed 19 February 2015].

8. Merinda Kaye Hensley, Sarah L. Shreeves, and Stephanie Davis-Kahl, "A Survey of Library Support for Formal Undergraduate Research Programs," College \& Research Libraries 75, no. 4 (2014): 422-41, available online at http://crl.acrl.org/content/75/4/422.full.pdf+html [accessed 7 February 2015].

9. Characteristics of Excellence in Undergraduate Research, ed. Nancy Hensel (Washington, D.C.: The Council on Undergraduate Research, 2012).

10. Ibid, 7.

11. Ibid, 16 .

12. Naomi Yaveneh Klos, "Beyond the Thesis Model: Making Undergraduate Research Work for YOU," in Creative Inquiry in the Arts \& Humanities, eds. Naomi Yaveneh Klos, Jenny Olin Shanahan, and Gregory Young (Washington, D.C.: Council on Undergraduate Research, 2011), $15-22$.

13. Jenny Olin Shanahan, "Scaffolding of Research Skills in the Humanities Curriculum," in Creative Inquiry in the Arts \& Humanities, eds. Naomi Yaveneh Klos, Jenny Olin Shanahan, and Gregory Young (Washington, D.C.: Council on Undergraduate Research, 2011), 7-14.

14. Hensley, Shreeves, Davis-Kahl, "A Survey of Library Support."

15. Summary data available online at http://classifications.carnegiefoundation.org/summary/ [accessed 24 September 2015].

16. The Carnegie Foundation does not classify non-U.S.-based institutions. Nine of the institutions represented in the survey were outside the United States.

17. Hensley, Shreeves, Davis-Kahl, "A Survey of Library Support," 431.

18. Ibid, 434-35.

19. From the original survey, the researchers identified the libraries that claimed their institution did not have an undergraduate research program and performed Internet searches of "Institutional name" + "undergraduate research." In every case, this led to institutional pages of symposia, grants-funding opportunities, institutional repositories, and the like.Hensley, Shreeves, Davis-Kahl, "A Survey of Library Support," 428. 